\title{
An improved method to estimate pigeon populations in urban areas
}

\author{
Zaidett Barrientos* \& Carolina Seas \\ Laboratorio de Ecología Urbana, Universidad Estatal a Distancia (UNED), 2050 San José, Costa Rica; zbarrientos@uned.ac.cr, cseas@uned.ac.cr \\ ${ }^{*}$ Correspondence.
}

Received 13-X-2017 • Corrected 14-XI-2017 • Accepted 11-XII-2017

\begin{abstract}
The Rock Pigeon, Columba livia, is rare in natural environments but extremely successful in urban areas all over the world. Management programs are important because it is considered a pest in many cities. Nevertheless, no appropriate evaluation of methods to estimate urban pigeon populations is available in the literature. We compared three methods: a) the frequently used Stratified grids; b) Point counts, i.e. total pigeon counts with a mechanic counter in sampling points with a $50 \mathrm{~m}$ radius; and c) Panoramas, $360^{\circ}$ panoramic photographs. In nine urban parks in central Costa Rica, we made 1350 counts in total and compared: coefficient of variation (to assess precision); accuracy; time counting or taking photographs in situ; time merging photographs, counting pigeons in photographs, or typing data; and advantages or disadvantages. The Panorama Method is cheap, precise, accurate, secure, fast and easy. It can be used as an indicator or to estimate the actual population.
\end{abstract}

Key words: Rock pigeon; urban parks; correction factor; population density; panoramic photograph.
RESUMEN: Comparación de tres métodos de estimación de poblaciones de palomas en áreas urbanas, y sus implicaciones en el manejo de plagas. La paloma de castilla, Columba livia, es poco común en ambientes naturales, pero tiene mucho éxito en áreas urbanas de todo el mundo. Se considera una plaga en muchas ciudades y, por lo tanto, los programas de gestión son importantes. Sin embargo, no se cuenta con una buena evaluación de los métodos para estimar las poblaciones de palomas urbanas en la literatura. Comparamos tres métodos: a) Cuadrículas estratificadas; b) Puntos de conteo, conteo total de palomas con un contador mecánico en puntos de muestreo con un radio de $50 \mathrm{~m}$; y c) Panoramas, fotografías panorámicas de $360^{\circ}$. Hicimos 1 350 conteos en nueve parques urbanos en el centro de Costa Rica, y comparamos: coeficiente de variación (para evaluar precisión); exactitud; tiempo al contar o tomar fotografías in situ; tiempo combinando fotografías, contando palomas en fotografías o escribiendo datos; y ventajas o desventajas. El método panorámico es económico, preciso, exacto, seguro, rápido y fácil. Se puede usar como un indicador o para estimar la población real.

Palabras clave: paloma de castilla; parques urbanos; factor de corrección; densidad poblacional; fotografías panorámicas.
The characteristics of species that have successfully adapted to cities are still under study (Møller, 2009). However, it seems that in the tropics, urban development offers an opportunity for wildlife species that need drier and warmer habitats. If these species also adapt to the food and water supplies provided by cities, they may cause economic damage and health problems (Monge, 2007; Marzluff \& Rodewald, 2008). Monitoring programs are necessary to generate management strategies applied to urban planning for population control, but affordable and reliable methods to estimate population size are still under development.

The Rock pigeon, Columba livia (Gmelin, 1789) is considered one of the most urban-adapted species and is found in almost every city in the world (Murton et al., 1972). It is considered an urban invader by some researchers as it is rare in natural environment and extremely abundant in urban areas like parks, buildings and other spaces (Marzluff \& Rodewald, 2008).

The population density of $C$. livia has been studied in Europe using stratified grids, distance sampling and the superimposed urban method (Uribe et al., 1984; Senar \& Sol, 1991; Sacchi et al., 2002; Senar et al., 2009; Hetmański et al., 2010; Ferman et al., 2011; Giunchi, Gaggini, Baldaccini, 2007; Amoruso, Fabbris, Mazza \& Caravello, 2014). However, these methods estimate pigeon population in a city as a whole and used controversial indexes (Giunchi, Vanni, Soldatini, Albores-Barajas \& Baldaccini, 2014).

There are fewer studies in the American continent. Some research has been conducted with urban 
avian fauna that include $C$. livia, but not focussed on Columbiformes (Stiles, 1990; Montalti \& Kopij, 2001; Seguí \& Caballero-Sadi, 2005; Yanga, 2011). Usually, data cannot be compared because the methods are variable: mist nets, transects, walk-in traps, banding, capture and recapture, and visual counts (Stiles, 1990; Montalti \& Kopij, 2001; Seguí \& Caballero-Sadi, 2005; Yanga, 2011), and there are no comparisons of methods applied simultaneously to the same population.

In Costa Rica urban parks management is done individually for each park, not for all parks in a city. Therefore, urban park managers urgently need a reliable, cheap and easy population estimation method that can be use in monitoring and control programs of single parks. Therefore, in this research, we compared three methods that can be employed in C. livia and other bird population estimation in urban parks, applied simultaneously to the same population to produce a valid comparison.

\section{MATERIAL AND METHODS}

Area description: The study was done in the Costa Rican Metropolitan Area which covers 3.8\% of the country (OUGAM, 2013). The provincial capitals of four of the seven Costa Rican provinces are located there: Cartago, Alajuela, Heredia and San José. We recorded data from nine urban parks located in the provincial capitals of San José, Alajuela and Cartago (three per province) (Fig. 1) (Digital appendix: Table 1).
These parks have similar conditions: size between 500 to $1000 \mathrm{~m}^{2}$; flat topography; squared shape; most trees were introduced species, mainly Ficus benjamina and Pinus sp.; there were between 5 and 30 trees per park; all are surrounded by streets, commercial areas, populated neighborhoods and a catholic church; all have at least some infrastructure (sidewalks, benches, sport areas and a kiosk); average altitude of $1100 \mathrm{msnm}$; two seasons, dry (December to April) and rainy (May to November); average annual rainfall around $2400 \mathrm{~mm}$; and average annual temperature of $20^{\circ} \mathrm{C}$ (IMN, 2013).

We visited each park five times during the rainy season (November 2013) and five times during the dry season (February and March 2014). In each visit we applied three sampling methods and made five repetitions of each. Therefore, we obtained 1350 counts in total. We visited the parks between 10 am and $2 \mathrm{pm}$.

We counted individuals roosting, perched, or on the ground; if birds started flying in circles or were disturbed in any way, we waited for the pigeons to go back to normal activity (perching, roosting, or foraging) and restarted the counting from the beginning.

Pigeon population estimation: We applied three sampling methods: 1) stratified grids, 2) point-counts, and 3) panoramas.

1. Stratified grids: This method has been used in Spain and consists in dividing the area of a city in which pigeon occur in $500 \times 500 \mathrm{~m}$ squares; the resulting

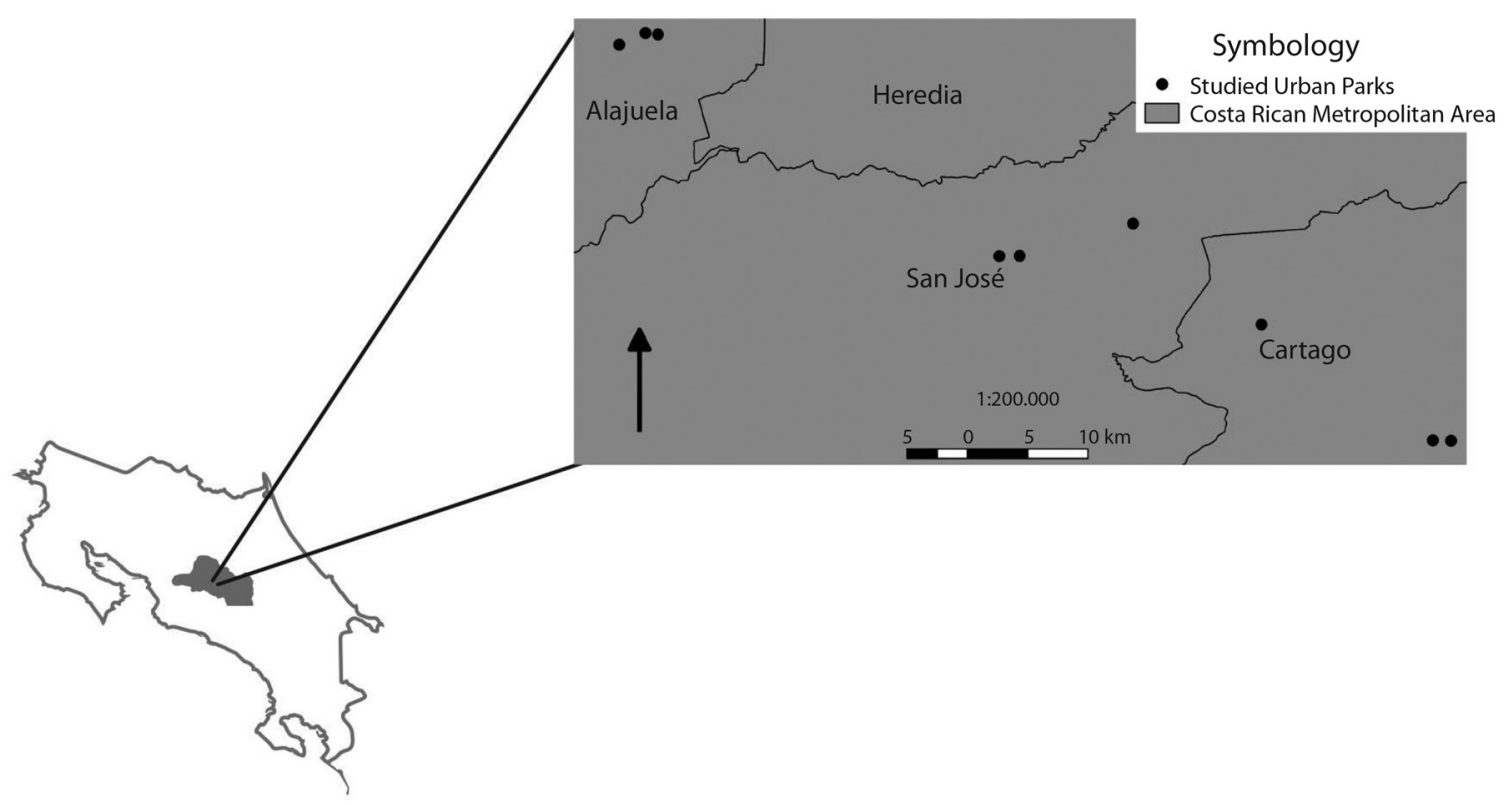

Fig. 1. Urban parks selected for the comparison of rock pigeons' population estimation methods in the Costa Rican Metropolitan Area. 
squares are classified in five categories according to the pigeon abundance; $34 \%$ of the squares are randomly selected and surveyed by walking between 10:00 am and 14:00 pm and counting individuals with a manual counter; sampling should be done during a non-reproductive season (Uribe et al., 1984; Senar et al., 2009). We made some adjustments considering that: 1) after a first general survey we did not find pigeons on streets or buildings outside the parks; 2) there are no studies about $C$. livia reproduction in the Neotropics; 3) our intention was to compare methods, not to give the population abundance; 4) in Costa Rica urban parks are managed by the municipality they belong to, therefore, they need a method to evaluate each park, not the city. Therefore, the stratified grid method we applied has the following differences:

a. our grids were placed only in parks;

b. we established nine counting points of $78,5 \mathrm{~m}^{2}(5 \mathrm{~m}$ radius) in each park and counted individuals for five minutes in each counting point.

2. Point-counts: standing in the center of the park, the observer makes a 360 degree turn while counting individuals with a manual mechanical counter in a radius of approximately $50 \mathrm{~m}$, limited by the streets and buildings that surround the park. This method is most widely used method in bird studies (Thompson, 2002).

3. Paranoramas: panoramic photographs, the observer takes panoramic photographs standing at the center of the park, while making a 360 degree turn; the camera is held $1.5 \mathrm{~m}$ above the ground. We merged the panoramic photographs with photoshop CS6 and counted the pigeons with Image Tool Software (Wilcox et al., 2002). This software puts a number above the counted pigeon in the panoramic photograph. The radius in this method is also about $50 \mathrm{~m}$ and, as in the previous method, is limited by the streets and buildings that surround the park.

Comparing methods: We calculated the coefficient of variation for the five count repetitions in each sampling date, for each method. We eliminated all data in which the population average was cero. This left 225 data sets, 75 for each method. Then we did a KruskalWallis analysis comparing the variation coefficient of the three methods.

Real population size: To obtain a reliable whole population size value, we chose a park with a small pigeon population, "Parque de Sabanilla" (Digital appendix: Table 1). To count the whole population, we fed the pigeons bread and took photographs that we analyzed with Image Tool Software. We repeated this procedure every two hours from 6:00 am to 6:00 pm during three days in October 2014. We stopped sampling when $57 \%$ of the counts $(n=21)$ gave the same result. For the evaluation of data accuracy, we considered the dry season average pigeon counts $(n=25)$ of the park selected for measuring the whole population size.

1. Method $X$ accuracy $=(\Sigma$ pigeon counts with method $X$ in the dry season / amount of counts with method $X$ in the dry season) / pigeon population size with the feeding method.

We also generated a correction factor for the recommended method with the total population.

2. Correction factor of the recommended method with the total population $=(\Sigma$ pigeon counts with the recommended method in the dry and rainy season/ amount of counts with the recommended method in the dry and rainy season) / ( $\Sigma$ pigeon counts while fed / amount of pigeon counts while fed).

\section{RESULTS}

Compared results appear in Table 1.

Average time per repetition: We found that the Panoramic photographs method requires less time for the whole procedure (time spent in the field plus time spend in the laboratory), and, as there is only one sampling point in each park, it does not require time for moving from one sampling site to the other (Chi square: $x^{2}=30$, d.f. $=2, p=0,0001$ ).

Mean coefficient of variation: Statistically the Panoramic and the Stratified methods are the most precise, as the repetitions counts results for a given park and a given sampling date are similar (Kruskal-Wallis $\mathrm{H}=7,06$, $\mathrm{n}=225, \mathrm{p}=0$,0216) (Tukey's range test: Panoramic method=102,15 A; Stratified method = 107,88 A; Counts in situ method $=128,97 \mathrm{~B}$; ranks with the same letter are equal p>0,005) (Table 1).

Method accuracy: The Panoramic and the Point Counts methods are the more accurate when compared with the real population size. We performed this analysis only with the Sabanilla Park. However, both methods slightly overestimate the population size (Table 1) (Fig. 2).

Advantages and disadvantages: The Panoramic is the best method with six advantages and only one disadvantages (Table 1).

The correction factor of the Panoramic method for the total population is 1,04 . This means that the amount obtained with the Panoramic method should divided with 1.04 to obtain the real size of the population in a given park. For example: if the panoramic method shows a 
TABLE 1

Time, precision and accuracy comparison of the three methods.

\begin{tabular}{|c|c|c|c|}
\hline & \multicolumn{3}{|c|}{ Method } \\
\hline & Stratified grids & Point-counts & Panoramic photographs \\
\hline $\begin{array}{l}\text { Average time spent in the field } \\
\text { per repetition }\end{array}$ & $\begin{array}{l}55 \text { minutes per repetition, } \\
\text { this includes specimen } \\
\text { counting and displacement } \\
\text { to the next counting point }\end{array}$ & $\begin{array}{l}25 \text { minutes per repetition, } \\
\text { this only includes specimen } \\
\text { counting. }\end{array}$ & $\begin{array}{l}3 \text { minutes per repetition, this only includes } \\
\text { time needed for taking photographs }\end{array}$ \\
\hline $\begin{array}{l}\text { Average time spent in the } \\
\text { laboratory }\end{array}$ & $\begin{array}{l}5 \text { minutes per repetition } \\
\text { typing data }\end{array}$ & $\begin{array}{l}5 \text { minutes per repetition } \\
\text { typing data }\end{array}$ & $\begin{array}{l}12 \text { minutes per repetition merging } \\
\text { photographs, counting pigeons in the } \\
\text { photographs and typing data }\end{array}$ \\
\hline $\begin{array}{l}\text { Total average time per repetition } \\
=\text { average time spent in the field } \\
\text { per repetition + average time } \\
\text { spent in the laboratory }\end{array}$ & 60 minutes & 30 minutes & 15 minutes \\
\hline $\begin{array}{l}\text { Mean coefficient of variation per } \\
\text { sampling date }\end{array}$ & $\begin{array}{l}2,69(S . D=3,89 ; \text { Min. }=0 \\
\text { Max.= } 14,14 ; n=75)\end{array}$ & $\begin{array}{l}3,6(S . D=4,78 ; \operatorname{Min} .=0 \\
\operatorname{Max} .=26,5 ; n=75)\end{array}$ & $\begin{array}{l}1,81(\mathrm{~S} . \mathrm{D}=3,04 ; \operatorname{Min} .=0 \\
\operatorname{Max} .=14,25 ; \mathrm{n}=75)\end{array}$ \\
\hline Method accuracy & 0,89 & 1,013 & 1,013 \\
\hline Advantages & $\begin{array}{l}\text { It is the most used method } \\
\text { for pigeon survey in cities. } \\
\text { Counting is relatively precise. } \\
\text { It provides a good } \\
\text { representation of the } \\
\text { park, even if it is big and } \\
\text { structurally complex. } \\
\text { It is less probable that } \\
\text { pigeons remain unseen } \\
\text { behind bushes or concrete or } \\
\text { metal structures. }\end{array}$ & $\begin{array}{l}\text { It requires less time in the } \\
\text { field than the stratified grid } \\
\text { method. }\end{array}$ & $\begin{array}{l}\text { Counting is relatively precise. } \\
\text { The farthest specimens can be counted } \\
\text { with the help of the zoom in the computer } \\
\text { Double counts and unseen specimens are } \\
\text { considerably reduced. } \\
\text { It requires less time in the field, reducing } \\
\text { danger of robbery in problematic parks. } \\
\text { Lower research budget needed, as it needs } \\
\text { less travel expenses. } \\
\text { It is the fastest method considering field } \\
\text { and laboratory time. } \\
\text { It provides a permanent record of the data } \\
\text { that can be re-checked and independently } \\
\text { verified later on, reducing the well- } \\
\text { documented potential for observer bias in } \\
\text { many bird survey techniques }\end{array}$ \\
\hline Disadvantages & $\begin{array}{l}\text { The amount of time needed } \\
\text { for displacement from one } \\
\text { sampling site to the other is } \\
\text { relatively high. } \\
\text { High probability of double } \\
\text { counting, or not counting } \\
\text { a specimen due to people } \\
\text { disturbance. } \\
\text { It requires more time in } \\
\text { the field increasing the } \\
\text { probability of robbery in } \\
\text { problematic parks. }\end{array}$ & $\begin{array}{l}\text { Time required in each } \\
\text { repetition is enough to } \\
\text { affect the counting precision } \\
\text { (double counts and unseen } \\
\text { specimens) due to people } \\
\text { interference. } \\
\text { It is difficult to identify and } \\
\text { count specimens that are } \\
\text { located far from the observer } \\
\text { or behind bushes or concrete } \\
\text { structures. } \\
\text { Pigeon population cannot be } \\
\text { properly measured in big and } \\
\text { structurally complex parks. }\end{array}$ & $\begin{array}{l}\text { Pigeon population cannot be properly } \\
\text { measured in big and structurally complex } \\
\text { parks with a single panoramic photograph. }\end{array}$ \\
\hline
\end{tabular}

S.D.= Standard deviation; Min. = minimum; Max. = maximum; $\mathrm{n}=$ sample size. 


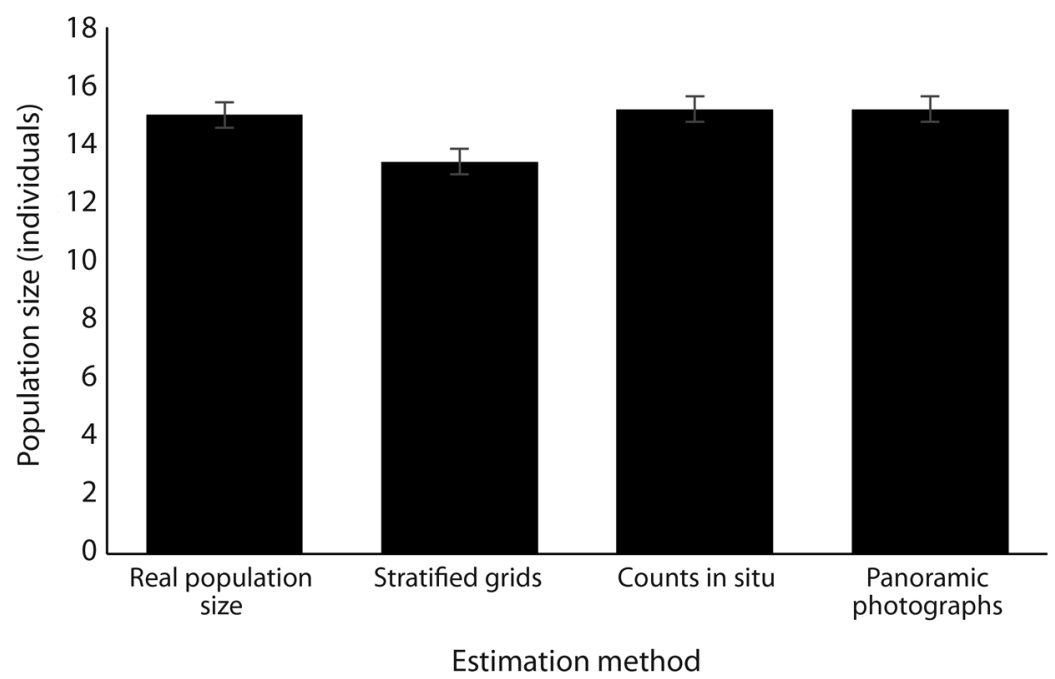

Fig. 2. Pigeon population in Sabanilla Park: real size and results of different estimation methods.

pigeon population of 60 , the real population size should be $60 / 1,04=57,7$, that means 58 pigeons.

\section{DISCUSSION}

Although the Stratified grids method is traditionally the most used method for pigeon surveys (Uribe et al., 1984; Senar \& Sol, 1991; Senar et al., 2009), and therefore the easier to compare with literature, we recommend the Panoramic photographs method for future population monitoring programs. This method is the best, if we consider precision and accuracy. Stratified grids underestimate the population, while point-counts and panoramic photographs are closer to the real population size. Panoramic photographs are cheaper, and require less repetitions and less field work, specially reducing the research budget because it needs less travel expenses. Besides this, the access to affordable digital cameras is no longer a problem in almost any country. All modern cell phones have high quality cameras allowing accurate photographs and high quality research at low cost in many fields (Krishna et al., 2009; Calabrese et al., 2011; Guerrero et al., 2012; Sicard et al., 2015). As this method needs less time in the field, it is also safer for the researchers considering that some urban parks are potentially insecure (Glaser, 1994; Carrión et al., 2006).

While the use of panoramic photographs is novel in pigeon surveys in urban areas, cameras to obtain population estimates has been used in several cases: in drones for wild life surveys, for corroboration of manual counts in bird counts in landfills, and in colonial breeding seabirds' surveys (Abd-Elrahman, Pearlstine \& Percival, 2005; Lobos, Bobadilla, Alzamora \& Thomsom, 2011; Huffeldt \& Merkel, 2013). In these examples, fixed photographs are useful as the researcher is outside of the habitat, but when the researcher is inside, panoramic photographs give better results.

The Panoramic photographs method has also been successfully used in monitoring colony-wide seabirds nesting behavior, pedestrian green perception in tropical urban areas and in rangeland monitoring (Nichols et al., 2009; Monge-Nájera et al., 2013; Lynch, Alderman \& Hobday, 2015). The scarcity of pigeon population data in tropical countries, the precision of the method and the conversion factor given in this paper, make the Panoramic photographs method a good starting point for pigeon monitoring programs, and possibly for other urban bird pest. This method can estimate the real population density, if the area of the park is considered in the study. It can also provide a relative index. Which of these options is chosen to establish the monitoring program depends on the objective of the management plan and if it includes only one park or several parks in a city. Another aspect that should be considered while establishing the monitoring program, is the park's structural complexity. If a total population size is desired and the park is big and structurally complex, we recommend a combination of methods: the selection of several points (Point counts method) followed by the Panoramic photographs method. 
This method can help in the establishment of pigeon and other bird monitoring programs in urban parks. However, the management strategy should consider the "Pigeon Paradox". This means that compared to other urban pest species, Columba livia, has relatively few negative impacts and people perception is quite favorable (Dunn, Gavin, Sánchez \& Solomon, 2006). Therefore, it should be used to increase environmental awareness and to promote citizen contact with nature as this helps ecosystem conservation (Durán, Barrientos \& Charpantier, 2016). The management strategy should guarantee that each pigeon population is kept stable, healthy and low, especially in tropical countries were ecosystems are highly diverse. Therefore, management strategies should include education programs and restoration plans that favor native species.

\section{ACKNOWLEDGEMENTS}

This work was supported by CONARE, Costa Rica. Project "Monitoreo de patógenos y de plomo en zonas urbanas costarricenses utilizando palomas (Columbia livia) y líquenes como bioindicadores". We thank Maribel Zúñiga, Rodrigo Salazar, Bernardo Rodriguez, Marcela Eduarte, Sergio Quesada and Cristhian Ureña for assistance, Carlos Andrés Campos for GIS support, Ligia Bermudez for statistical support and Julián MongeNájera for suggestions to improve an early draft.

\section{REFERENCES}

Abd-Elrahman, A., Pearlstine, L., \& Percival, F. (2005). Development of pattern recognition algorithm for automatic bird detection from unmanned aerial vehicle imagery. Surveying and Land Information Science, 65(1), 37.

Amoruso, I., Fabbris, L., Mazza, M., \& Caravello, G. (2014). Estimation of Feral Pigeon (Columba livia) population size using a novel Superimposed Urban Strata (SUS) method. Urban ecosystems, 17(2), 597-612. doi: 10.1007/ s11252-013-0323-2

Calabrese, F., M. Colonna, P. Lovisolo, D. Parata, \& C. Ratti. (2011). Real-time urban monitoring using cell phones: A case study in Rome. IEEE Transactions on Intelligent Transportation Systems, 12(1), 141-151.

Carrión Mena, F., \& Núñez-Vega, J. (2006). La inseguridad en la ciudad: hacia una comprensión de la producción social del miedo. Eure (Santiago), 32(97), 7-16.

Dunn, R. R., Gavin, M. C., Sanchez, M. C., \& Solomon, J. N. (2006). The pigeon paradox: dependence of global conservation on urban nature. Conservation biology, 1814-1816.
Durán, M., Barrientos, Z., \& Charpentier, C. (2016). Percepción ambiental de escolares urbanos: influencia de áreas verdes, financiamiento y sexo en Costa Rica. UNED Research Journal, 8(1), 31-39.

Ferman, L. M., Peter, H.-U., \& Montalti, D. (2011). A study of feral pigeon Columba livia var. in urban and suburban areas in the city of Jena, Germany. Arxius de Miscellània Zoològica, 8, 1-8.

Giunchi, D., Gaggini, V., Baldaccini, N. E. (2007). Distance sampling as an effective method for monitoring feral pigeon (Columba livia f. domestica) urban populations. Urban Ecosyst, 10, 397-412.

Giunchi, D., Vanni L., Soldatini C., Albores-Barajas Y. V., \& Baldaccini N. E. (2014). Old and novel methods for estimating Feral Pigeons (Columba livia f. domestica) population size: a reply to Amoruso et al. (2013). Urban Ecosystems, 17, 1-4.

Glaser, M. (1994). Security v. park and recreation service delivery: reduced effectiveness of public investment. Journal of Urban Affairs, 16(4), 359-369.

Guerrero, N. R., Quintero, M. A. O., \& Naranjo, J. C. P. (2012). Determinación del área foliar en fotografías tomadas con una cámara web, un teléfono celular o una cámara semiprofesional. Revista Facultad Nacional de Agronomía Medellín 65(1), 6399-6405.

Hetmański, T., Bocheński, M., Tryjanowski, P., \& Skórka, P. (2010). The effect of habitat and number of inhabitants on the population sizes of feral pigeons around towns in northern Poland. European Journal of Wildlife Research, 57(3), 421-428. doi:10.1007/s10344-010-0448-z

Huffeldt, N. P., \& Merkel, F. R. (2013). Remote time-lapse photography as a monitoring tool for colonial breeding seabirds: a case study using thick-billed murres (Uria lomvia). Waterbirds, 36(3), 330-341.

IMN (Instituto Metereológico Nacional). (2013). Clima en Costa Rica. Retrieved from https://www.imn.ac.cr/web/imn/ inicio

Krishna, S., Boren, S. A., \& Balas, E. A. (2009). Healthcare via cell phones: a systematic review. Telemedicine and e-Health, 15(3), 231-240.

Lobos, G., Bobadilla, P., Alzamora, A., \& Thomsom, R. F. (2011). Patrón de actividad y abundancia de aves en un relleno sanitario de Chile central. Revista chilena de historia natural, 84(1), 107-113.

Lynch, T. P., Alderman, R., \& Hobday, A. J. (2015). A high-resolution panorama camera system for monitoring colony-wide seabird nesting behaviour. Methods in Ecology and Evolution, 6(5), 491-499.

Nichols, M. H., Ruyle, G. B., \& Nourbakhsh, I. R. (2009). Very-highresolution panoramic photography to improve conventional rangeland monitoring. Rangeland ecology \& management, 62(6), 579-582. 
Marzluff, J., \& Rodewald, A. (2008). Conserving biodiversity in urbanizing areas: nontraditional views from a bird's perspective. Cities and the Environment (CATE), 1(2), 6.

Monge, J. (2007). ¿Qué son plagas vertebradas? Agronomía costarricense, 31(2), 111-121.

Monge-Najera, J., Barrientos, Z., \& Zúñiga-Solís, M. (2013). A Satellite and Ground Evaluation of Urban Vegetation and Infrastructure in the Landscape of a Tropical City: Heredia, Costa Rica. Cities and the Environment (CATE), 6(1), 12

Montalti, D., \& Kopij, G. (2001). Bird Community of Inner La Plata City, Argentina. Acta Ornithologica, 36(2), 161-164. doi:10.3161/068.036.0209

Møller, A. P. (2009). Successful city dwellers: a comparative study of the ecological characteristics of urban birds in the Western Palearctic. Oecologia, 159, 849-858. doi: 10.1007/s00442-008-1259-8

Murton, R. K., Thearle, R. J. P., \& Thompson, J. (1972). Ecological studies of the feral pigeon Columba livia var. I. Population, breeding biology and methods of control. Journal of applied ecology, 835-874.

OUGAM (Observatorio Urbano de la Gran Area Metroplitana). (2013). La Gran Area Metropolitana. Universidad de Costa Rica, San José, Costa Rica. Retrieved from http:// ougam.ucr.ac.cr/index.php/la-gam

Sacchi, R., Gentilli, A., Razzetti, E., \& Barbieri, F. (2002). Effects of building features on density and flock distribution of feral pigeons Columba livia var. domestica in an urban environment. Canadian Journal of Zoology, 80(1): 48-54. doi:10.1139/z01-202
Seguí, R., \& Caballero-Sadi, D. (2005). Estudio de la comunidad de aves en parques de Montevideo urbano. VIII Jornadas de Zoología del Uruguay, 1-11.

Senar, J. C., Carrillo, J., Arroyo, L., Montalvo, T., \& Peracho, V. (2009). Estima de la abundancia de palomas (Columba livia var.) de la ciudad de Barcelona y valoración de la efectividad del control por eliminación de individuos. Arxius de Miscel/lània Zoològica, 7, 62-71.

Senar, J.C., \& Sol, D. (1991). Censo de palomas (Columba livia var.) de la ciudad de Barcelona: Aplicación del muestreo estratificado con factor de corrección. Butlleti del Grup Catala d'Anellament, 8: 19-24.

Sicard, C., Glen, C., Aubie, B., Wallace, D., Jahanshahi-Anbuhi, S., Pennings, K... \& Filipe, C. D. (2015). Tools for water quality monitoring and mapping using paper-based sensors and cell phones. Water research, 70, 360-369.

Stiles, F. G. (1990). La avifauna de la Universidad de Costa Rica y sus alrededores através de veinte años (1968-1989). Revista de Biología Tropical, 38(2b), 361-381.

Thompson, W. L. (2002). Towards reliable bird surveys: accounting for individuals present but not detected. The Auk, 119(1), 18-25.

Uribe, F., Colom, L., Camerino, M., Ruiz, J., \& Senar, C. (1984). Censo de las palomas semidomésticas. Misc Zool, 8, 237-244.

Wilcox, C. D., Dove, S. B., McDavid, W. D., \& Greer D. B. (2002). UTHSCSA Image tool. IT Version, 3.

Yanga, S. (2011). A preliminary survey for avian pathogens in Columbiform birds on Socorro Island, Mexico. Pacific Conservation, 17, 11-21.

\section{EDITED BY FRANK GONZÁLEZ}

See Digital Appendix at: / Ver Apéndice digital en: http://investiga.uned.ac.cr/revistas/index.php/cuadernos 